\title{
Characterization of Dissolved Organic Matter in the Piauí River Estuary, Northeast Brazil
}

\author{
Adnivia Santos Costa, Elisangela de Andrade Passos, * Carlos A. B. Garcia and \\ José do Patrocinio H. Alves
}

Departamento de Química, Universidade Federal de Sergipe, 49100-000 São Cristóvão-SE, Brazil

\begin{abstract}
A espectroscopia de fluorescência e o carbono orgânico dissolvido (COD) foram utilizados para caracterização da matéria orgânica dissolvida (MOD) no estuário do Rio Piauí, um estuário tropical situado no Estado de Sergipe, nordeste do Brasil. As intensidades de fluorescência foram maiores no período chuvoso e menores no período seco, evidenciando que a variabilidade das propriedades fluorescentes da MOD é ditada, principalmente, pela descarga fluvial e pelo processo de diluição no estuário. No período chuvoso, os compostos tipo triptofano e húmicos predominaram na composição da MOD, enquanto no período seco ocorreu um aumento significativo dos constituintes tipo proteínas. As relações das intensidades de fluorescência com a salinidade sugerem um comportamento não conservativo para a MOD fluorescente. O COD mostrou um comportamento conservativo no período seco e não conservativo no período chuvoso, com produção de COD na parte superior do estuário. A complexação da MOD com o $\mathrm{Cu}(\mathrm{II})$, estudada usando a técnica de supressão da fluorescência, evidenciou o potencial de complexação dos fluoróforos tipo proteínas, tripofano e húmico.
\end{abstract}

Fluorescence spectroscopy and dissolved organic carbon (DOC) measurements were used to characterize the dissolved organic matter (DOM) in the Piauí River estuary, a tropical estuary situated in the State of Sergipe, Northeast Brazil. Fluorescence intensities were greater during the rainy period than the dry period, demonstrating that variability in the fluorescence properties of the DOM was determined mainly by the fluvial discharge and the dilution processes occurring in the estuary. During the rainy period, tryptophan-like and humic substances were the main components of the DOM, while during the dry period there was a significant increase of proteinlike constituents. Relationships identified between fluorescence intensities and salinity were indicative of non-conservative behavior of the fluorescent DOM. DOC showed behavior that was conservative during the dry period, and non-conservative during the rainy period, with production of DOC in the upper reaches of the estuary. The complexation of DOM with $\mathrm{Cu}(\mathrm{II})$, studied using the fluorescence suppression technique, showed the complexation potentials of protein, tryptophan and humic type fluorophores.

Keywords: natural organic matter, Piauí River, estuary, fluorescence

\section{Introduction}

Dissolved organic matter (DOM) is a complex heterogeneous mixture of macromolecules formed by the decomposition of biological material derived from animals or plants. DOM represents one of the main reservoirs of carbon on the Earth's surface, and exhibits a variety of ecologically and geochemically important properties including the ability to absorb light, bind with trace metals and organic pollutants, adsorb substances onto its

*e-mail: elisapassos@gmail.com surface and undergo aggregation, as well as photochemical reactivity. ${ }^{1-3}$

The DOM present in natural waters can have either autochtone or allochtone origins. Allochtone organic matter is introduced into aquatic systems by leaching from the soil, and comprises dissolved organic matter derived from the soil as well as from direct decomposition of plant foliar litter. Autochtone organic matter is formed in the aquatic medium itself by the chemical, photochemical and bacterial degradation of natural biological material. It is more labile, and is therefore preferentially utilized, degraded and mineralized during heterotrophic activity. ${ }^{4}$ 
DOM derived from terrestrial origins predominates in fluvial systems and is more refractory, while in ocean waters DOM results almost entirely from the photosynthetic activity of phytoplankton, producing organic compounds that are more susceptible to processes of degradation and transformation. 5,6

Humic substances are normally the largest fraction of total organic carbon in natural waters. ${ }^{7}$ Humic and fulvic acids are the most important contributors to aquatic humic substances, and differ from each other in terms of their molecular mass, chemical composition, degree of aromaticity and optical properties. ${ }^{8,9}$ Terrestrial sources can be the predominant contributors to organic matter in coastal regions, but overall represent only $2-3 \%$ of oceanic organic matter, whose main source $(95 \%)$ is autochtone production. ${ }^{5}$

The optical properties of natural waters are determined by the optically active fraction of the DOM, which is usually termed colored dissolved organic matter (CDOM). This DOM fraction absorbs most strongly in the ultraviolet region of the spectrum, and exhibits the special property of fluorescence emission following light absorption. The CDOM directly influences the spectral quality of light in the water column, and indirectly affects primary production (either stimulating or inhibiting it), due to changes in both the exposure of aquatic organisms to dangerous UV radiation and temperature stratification. ${ }^{10}$ Photochemical reactions involving CDOM produce inorganic carbon, low molecular weight organic compounds, and compounds of phosphorus and nitrogen. ${ }^{11,12} \mathrm{CDOM}$ is also able to complex trace metals, which can subsequently be released to the environment during mineralization. ${ }^{10}$

Fluorescence spectroscopy techniques have been widely employed in studies involving characterization of the sources, degradation and transformation of DOM in natural waters. ${ }^{13-20}$ In addition to its greater sensitivity (by between one and three orders of magnitude) compared to UV-Vis absorption, fluorescence enables the discrimination of different DOM chromophores that absorb at similar wavelengths. ${ }^{21}$ Fluorescence measurements have traditionally been presented in the form of an emission spectrum, following irradiation at a fixed wavelength. ${ }^{22}$ More recently, synchronized fluorescence scanning has been developed, which involves the measurement of an emission spectrum at a $\Delta \lambda\left(\lambda_{\text {emission }}-\lambda_{\text {excitation }}\right)$ of between 20 and $60 \mathrm{~nm},{ }^{23}$ while rapid detection of the excitationemission matrix in three dimensions (EEM) has also now become possible. The fluorescence EEM technique has the advantage of being able to capture several spectra over a wide range of excitation-emission wavelengths, although a series of scans are required in order to complete the measurement. Synchronized fluorescence is a bidimensional technique, requiring only a single scan, and has been satisfactorily used to identify the sources of organic material in aquatic systems. ${ }^{24,25}$ Synchronized fluorescence spectra for aquatic DOM usually reveal the presence of four broad peaks, attributed to: (i) compounds having structural characteristics of aromatic amino acids associated with proteins and protein fragments (at wavelengths of 270-300 nm); (ii) compounds possessing two tryptophan-like condensed rings $(320-370 \mathrm{~nm})$; (iii) fulvic acids (370-400 nm); and (iv) humic acids $(420-480 \mathrm{~nm}){ }^{26}$

Interest in the sources, transport and transformations of DOM in estuarine systems has been stimulated by the importance of estuaries as an interface between terrestrial and marine ecosystems. ${ }^{20}$ Terrestrial organic matter entering the estuary can constitute a microbial food source, or a geological reservoir of organic carbon as a result of the deposition of refractory DOM in marine sediments. ${ }^{1,27}$ Meanwhile, it has proved difficult to quantify the burden of terrestrial organic matter arriving in the marine system, due to a combination of factors including dilution by oceanic waters containing lower contents of DOM, mixing with estuarine sources of organic matter, photodegradation and microbial degradation, and mineralization-removal. ${ }^{28,29}$

Fluorescence spectroscopy has been extensively used in studies of the estuarine mixing process, for characterization and differentiation of masses of water. ${ }^{26,30-33}$ In the present work, fluorescence spectroscopy was used to accompany the evolution of DOM during the mixing of fluvial and marine waters in the Piauí River estuary, which is a tropical estuary situated in the State of Sergipe, northeast Brazil. The technique enabled the separation and quantification of the fluorescent DOM originating from terrestrial material (humic substances) and that produced in the local environment from the degradation of natural biologic material. The behaviors of DOC and fluorescent DOM during estuarine mixing were also investigated in order to identify changes that may occur in the dissolved organic fraction as a result of changes in physical and chemical parameters and seasonal variability. The fluorescence suppression technique was also used to make a preliminary assessment of the role of different fluorescent sites in the process of complexation with copper.

\section{Experimental}

\section{Sampling procedure}

The Piauí River, located in the Southern region of Sergipe State, drains an area of $4150 \mathrm{~km}^{2}$ and flows a distance of $132 \mathrm{~km}$ before discharging into the Atlantic 
Ocean. The estuarine region covers an area of around $60 \mathrm{~km}^{2}$, has an average depth of $5 \mathrm{~m}$ and is characterized by a well-mixed water column with a circulation pattern dominated largely by tidal currents. The upper estuary receives wastewater discharges from domestic sources, textile industries, and juice and food processing industries located in the city of Estancia. . $^{34,35}$

Surface water samples were collected during periods of both low and high tides, at eight sites distributed along the estuary (Figure S1). Polyethylene receptacles were used, and the samples were stored in ice in the dark, until arrival at the laboratory. They were then immediately filtered using $0.45 \mu \mathrm{m}$ porosity pre-combusted glass fiber filters, and stored in the dark at $4{ }^{\circ} \mathrm{C}$ until all analyses had been completed. All the vessels employed were rinsed with ultrapure water (Milli-Q system, Millipore), and tested for cleanliness using the fluorescence procedure. This procedure of storage and filtration has been used in most of the published studies in this area, and is considered to be the most appropriate to minimize changes in fluorescence of the samples with time. ${ }^{36}$

\section{Synchronized fluorescence analysis}

The synchronized fluorescence spectra for the water samples were recorded using a Perkin Elmer LS45 spectrofluorimeter, fitted with a xenon lamp as the excitation source. All measurements were performed using a constant difference of $30 \mathrm{~nm}$ between the excitation and emission wavelengths, a slit width of $10 \mathrm{~nm}^{24,26}$ and a scan over the excitation wavelength range $250-550 \mathrm{~nm}$. The spectra were blank-corrected (using measurements of Milli-Q water), and the fluorescence intensities were expressed using arbitrary units.

\section{Analysis of dissolved organic carbon}

The concentrations of dissolved organic carbon were measured by combustion of the sample at $950{ }^{\circ} \mathrm{C}$ in a total organic carbon analyzer (Shimadzu, Model TOC-5000A). The instrument was calibrated using standard solutions of potassium hydrogen phthalate, diluted to different concentrations according to the estimated DOC content of the samples. The value obtained for each sample was the average of at least three satisfactory injections in terms of the coefficient of variation $(\leq 2 \%)$.

\section{Fluorescence quenching titration}

The technique of fluorescence suppression based on the modified Stern-Volmer model ${ }^{37}$ was used to study the complexation between DOM and $\mathrm{Cu}(\mathrm{II})$. Different volumes ( 10 to $80 \mu \mathrm{L}$ ) of a $0.01 \mathrm{~mol} \mathrm{~L}^{-1}$ solution of $\mathrm{Cu}$ (II) were added to a series of glass flasks containing $20 \mathrm{~mL}$ of estuary water. The flasks were shaken, and left to stand in the dark for $24 \mathrm{~h}$ at room temperature in order to reach complexation equilibrium. Synchronized fluorescence spectroscopy was used to accompany the decrease of fluorescence intensity that followed each addition of $\mathrm{Cu}$ (II) solution. Titration was performed in triplicate at the natural sample $\mathrm{pH}(7.8)$ and salinity (12.0). During the titration the $\mathrm{pH}$ was maintained at $7.8 \pm 0.1$ and the total sample volume did not exceed the limit of $20.08 \mathrm{~mL}$. The complexation parameters were estimated by application of the modified Stern-Volmer equation, assuming the formation of 1:1 complexes between the DOM and $\mathrm{Cu}(\mathrm{II})$.

\section{Results and Discussion}

\section{Variation of fluorescence intensity and DOC along the estuary}

In the synchronized fluorescence method the excitation and emission wavelengths are varied simultaneously, maintaining a constant wavelength interval $(\Delta \lambda)$ between them. The form of the synchronized spectrum and the dimensions of the bands depend on the value of $\Delta \lambda$ selected. ${ }^{38}$ Four peaks appeared in the synchronized spectra of the estuary samples, at wavelengths of 278-280 nm (peak I), $350 \mathrm{~nm}$ (peak II), $385 \mathrm{~nm}$ (peak III) and 458-460 nm (peak IV) (Figures 1 and 2). Peak I has previously been associated with fluorophores originating from microbial primary production, and corresponds to a more labile fraction of the DOM..$^{39-42}$ Peaks II, III and IV are related to compounds containing two condensed rings, fulvic acids and humic acids, respectively. ${ }^{40,43}$ Peak II has also been related to discharges of domestic sewage and effluents from landfill sites, and for this reason has been used as a tracer for the presence of such material in natural waters. ${ }^{44-46}$ In the present case, peak II was probably associated with urban and industrial discharges into the Piauí River in the vicinity of the city of Estância, which are then transported downstream into the estuarine region. Spectra were obtained for samples of different salinities, collected in the dry (October 2007) and rainy (July 2008) periods along the entire length of the estuary, from its upper reaches $(\mathrm{s}=0.1)$ to the point of maximum mixing with oceanic water $(\mathrm{s}=28)$.

The absorbances at $254 \mathrm{~nm}$ were measured prior to the spectrofluorimetric analyses. The absorbances of all samples were low $(<0.1$, Table 1$)$; under these conditions the fluorescence intensity is proportional to 


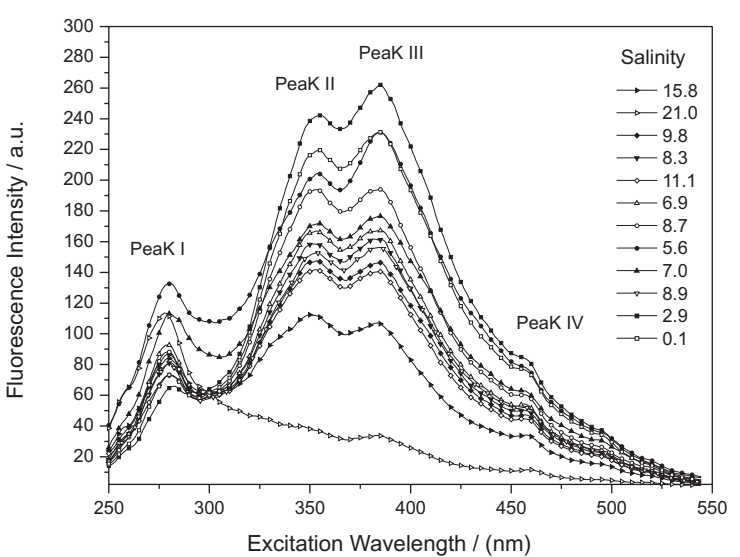

Figure 1. Synchronized fluorescence spectra for water collected from the Piauí River estuary in July 2008, according to salinity. The numbers in the spectra identify the peaks.

the concentration of the fluorescent compounds, so that corrections related to the inner-filtering effect ${ }^{47}$ were not required. The $\mathrm{pH}$ ranged from 7.8 to 8.2 during the dry period, and from 8.2 to 8.6 during the rainy period, except for site $\mathrm{P} 8$ where the $\mathrm{pH}$ was 7.6. The effects of changes of $\mathrm{pH}$ on the fluorescence properties of water have generally been taken into consideration when the $\mathrm{pH}$ fluctuates by around \pm 2 units. $^{36}$

The fluorescence spectra showed qualitative and quantitative differences for the samples collected at different salinities. In July (Figure 1), peaks II and III showed the greatest fluorescence intensities, which suggests that during the rainy period there was a large contribution from fluvial water rich in humic substances. In October (Figure 2), the greatest intensity was measured for peak I, reflecting the influence of saline water on estuarine mixing

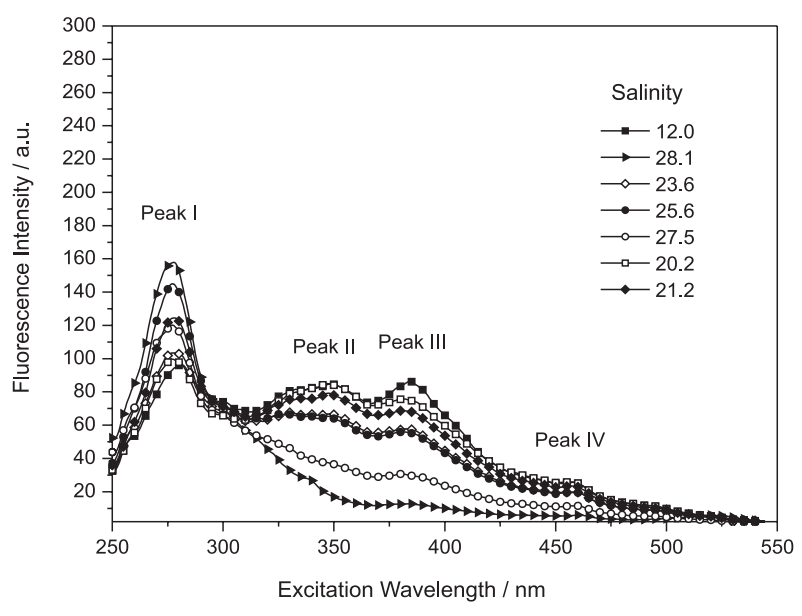

Figure 2. Synchronized fluorescence spectra for water collected from the Piauí River estuary in October 2007, according to salinity. The numbers in the spectra identify the peaks.

during the dry period. The spectra obtained for the most saline samples ( $>$ > 27) were qualitatively different from the others, since they consisted almost entirely of peak I, which was associated with organic matter derived from coastal biological activity.

During both periods there was a general decrease in the fluorescence intensity of all components as salinity increased, due to dilution, and a relative increase and dominance of protein-like compounds (peak I) with increasing distance from the fluvial region. The fluorescence intensities were greater in the rainy period than the dry period, and therefore increased in line with the river flow rate, demonstrating that variability of the fluorescent properties of the DOM was determined mainly by the fluvial discharge and by the dilution of terrestrial

Table 1. Characteristics and optical properties of water from the Piauí River estuary, collected during the dry (October 2007) and rainy (July 2008) periods

\begin{tabular}{|c|c|c|c|c|c|c|c|c|}
\hline \multirow{2}{*}{ Site } & \multicolumn{4}{|c|}{ Dry period (October 2007) } & \multicolumn{4}{|c|}{ Rainy period (July 2009) } \\
\hline & $\mathrm{pH}$ & Salinity & $\mathrm{DOC}^{1} /\left(\mathrm{mg} \mathrm{L}^{-1}\right)$ & $\mathrm{A}_{254}{ }^{2} / \mathrm{nm}$ & $\mathrm{pH}$ & Salinity & $\mathrm{DOC}^{1} /\left(\mathrm{mg} \mathrm{L}^{-1}\right)$ & $\mathrm{A}_{254}{ }^{2} / \mathrm{nm}$ \\
\hline \multirow[t]{2}{*}{ P1 } & 8.0 & 27.5 & 4.61 & 0.000 & 8.4 & 15.8 & 3.65 & 0.020 \\
\hline & 8.2 & 27.8 & 2.41 & 0.000 & 8.6 & 21.0 & 2.94 & 0.000 \\
\hline \multirow[t]{2}{*}{$\mathrm{P} 2$} & 7.8 & 23.9 & 5.38 & 0.006 & 8.3 & 9.8 & 5.55 & 0.085 \\
\hline & 8.0 & 26.3 & 5.06 & 0.000 & 8.5 & 11.1 & 5.97 & 0.020 \\
\hline \multirow[t]{2}{*}{ P3 } & 7.8 & 23.8 & 5.34 & 0.007 & 8.3 & 8.9 & 5.21 & 0.189 \\
\hline & 7.9 & 25.6 & 5.06 & 0.000 & 8.5 & 11.0 & 5.79 & 0.020 \\
\hline \multirow[t]{2}{*}{$\mathrm{P} 4$} & 7.7 & 21.2 & 5.81 & 0.023 & 8.4 & 8.3 & 6.08 & 0.107 \\
\hline & 7.8 & 23.4 & 5.70 & 0.000 & 8.4 & 8.7 & 6.61 & 0.070 \\
\hline \multirow[t]{2}{*}{ P5 } & 7.8 & 12.0 & 6.31 & 0.064 & 8.2 & 2.9 & 9.59 & 0.128 \\
\hline & 7.6 & 20.2 & 5.82 & 0.028 & 8.4 & 5.6 & 9.03 & 0.146 \\
\hline \multirow[t]{2}{*}{ P6 } & 7.7 & 20.8 & 5.48 & 0.020 & 8.3 & 7.0 & 5.65 & 0.105 \\
\hline & 7.6 & 20.2 & 6.01 & 0.025 & 8.3 & 6.9 & 6.02 & 0.056 \\
\hline \multirow[t]{2}{*}{ P7 } & 7.9 & 23.6 & 6.20 & 0.040 & 8.3 & 8.8 & 7.38 & 0.128 \\
\hline & 8.0 & 28.1 & 4.64 & 0.000 & 8.3 & 8.8 & 7.54 & 0.134 \\
\hline P8 & 7.8 & 0.1 & 7.93 & 0.018 & 7.6 & 0.1 & 8.46 & 0.129 \\
\hline
\end{tabular}

${ }^{1}$ Dissolved organic carbon. ${ }^{2}$ Absorbances at $254 \mathrm{~nm}$. 
DOM by coastal ocean waters. It is also possible to discern the variation in the composition of the DOM between the dry and rainy periods. During the rainy period, the tryptophan-like and humic substances (peaks II, III and IV) almost entirely dominated the DOM composition, with the sum of the fluorescence intensities of peaks II, III and IV representing $79 \%$ of the total fluorescence, and peak I representing $21 \%$. During the dry period, the contribution of the humic components fell to $52 \%$, while that of the protein-like substances reached $48 \%$. Previous studies have also found that the humic fraction of CDOM increases during the rainy period in regions directly influenced by fluvial discharges, reflecting the larger continental input from allochthonous DOM during this period. ${ }^{32,48}$

The relationships obtained between fluorescence intensity and salinity are illustrated in Figures 3 and 4. The samples collected in July (Figure 3) showed almost identical changes for peaks II and III, with an increase of the intensity of fluorescence in the salinity range from 0 to 3 , after which the intensity decreased. At salinities greater than 9 there was an inverse linear relationship between salinity and the intensities of peaks II and III. The intensity of fluorescence peak IV decreased linearly with salinity. In October (Figure 4), the intensities of fluorescence peaks II, III and IV showed a slight increase in the salinity range from 0 to 12, after which there was a decrease. A linear relationship was only observed at salinities greater than 20 . During both periods, the intensity of peak I was reduced in the central part of the estuary, and then increased with salinity, indicating an increase in the concentration of organic matter derived from coastal biological activity in the region where the marine influence was strongest. Hence, in the Piauí River estuary the behavior of fluorescent DOM could not be described by a conservative mixing process. The increase in fluorescence intensity of peaks II and III and reduction in peak I (Figures 4 and 5) indicate the addition and removal of fluorescent organic matter, respectively, during the mixing of fluvial and marine waters. For mixing to be considered conservative, measurements of the fluorescence intensity along the estuary should display a linear variation in relation to salinity, characterizing a process of simple dilution of the fluorescent DOM during estuarine mixing.

The concentrations of DOC varied between 2.41 and $9.59 \mathrm{mg} \mathrm{L}^{-1}$, and were generally slightly higher for the samples collected in July 2007, which is in agreement with the greater fluorescence intensities recorded for this period. Significant differences between the concentrations measured for the two periods were only observed for samples from site 5 (Table 1), which could be due to local loadings of DOM derived from areas of mangrove

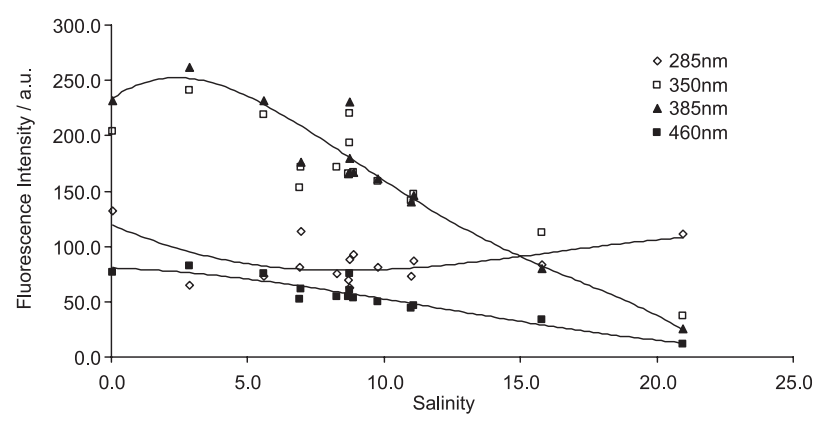

Figure 3. Variation of the intensity of the different fluorescence peaks according to salinity (July 2008).

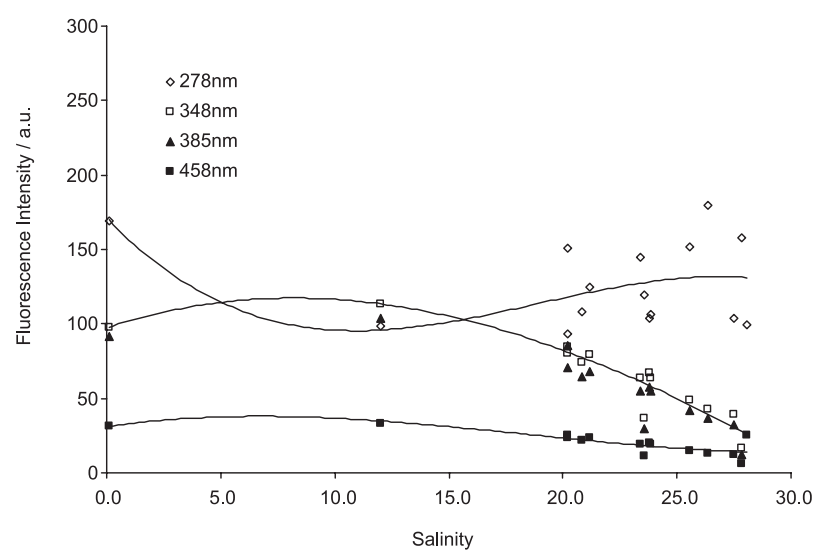

Figure 4. Variation of the intensity of the different fluorescence peaks according to salinity (October 2007).

vegetation. For the same samples, variation of the DOC content as a function of salinity (Figure 5) was indicative of behavior that was different according to season. During the dry period (October 2007), there was an inverse linear relationship between the DOC concentration and salinity, indicating a conservative dilution of the terrestrial organic matter entering the estuary. This behavior was different to that indicated by the variation of fluorescence intensity, which suggested an input of fluorescent material in the upper reaches of the estuary, and removal in the intermediate region. The microbial transformation of non-fluorescent DOM into a fluorescent product, as suggested by Rechelle-Newall and Fisher, ${ }^{49}$

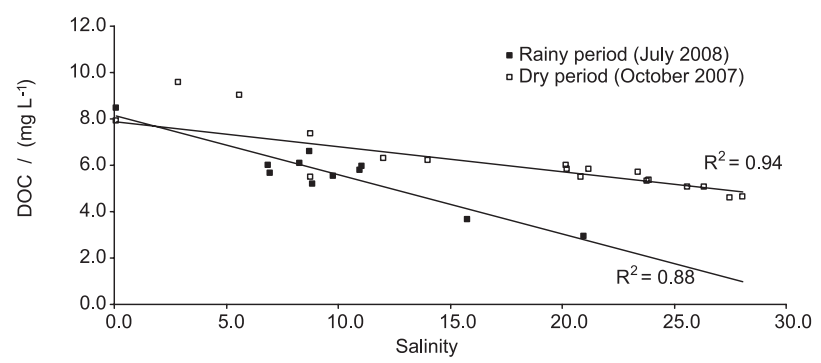

Figure 5. DOC as a function of the salinity of water from the Piauí River estuary during the dry (October 2007) and rainy (July 2008) periods. 
can lead to increased fluorescence intensity in the region of low salinity. This process is particularly significant in systems that contain high levels of anthropogenic DOC, as in the Scheldt estuary. ${ }^{50}$ The removal in the intermediate region of the estuary could be attributed to flocculation of fluorescent organic matter from terrestrial origins due to the effect of increased salinity. Similar behavior was found by Callahan et al..$^{51}$ in the estuary of the Pearl River (China).

During the rainy period (July 2008), there was an input of DOC into the upper estuary, rather than simple conservative mixing, and a similar trend was observed for the fluorescent organic material. Increased concentrations of DOC in estuaries have been attributed to the transformation of particulate organic matter into dissolved forms, or desorption of compounds associated with the particulate matter. The organic compounds released then result in an increase of fluorescence intensity, relative to that which would be expected in the presence of dilution alone. ${ }^{32,50}$

In estuarine regions, DOM is influenced by a variety of physical processes, and both conservative and nonconservative behavior has been observed..$^{26,28,32,49} \mathrm{In}$ estuaries along the southwest coast of Florida, located in the Ten Thousands Island and Whitewaste Bay, DOC showed a conservative behavior during the dry period in the years 2001 and 2002. However, in 1999 conservative behavior was not observed, with increased DOC in regions of the estuary near the mangrove areas. This atypical deviation was attributed to the heavy rains that occurred in that year, resulting in a greater transport of DOM from the mangrove area to the estuary. ${ }^{26}$ In the Gironde estuary (France), the DOC showed non-conservative behavior and consumption of DOC in winter in the region of average salinity, and production in that region during the summer. ${ }^{32}$ Similar results were found in the estuaries of the Tamar (England), Sado (Portugal) and Ems (The Netherlands), where DOC showed the same non-conservative behavior, with production during the summer. ${ }^{50,52}$ To explain these deviations, the authors attributed the increased concentrations of DOC to desorption of organic compounds from particulate matter in the maximum turbidity zone, or the resuspension of bottom sediment. For the regions of average salinity, there is a decrease in the concentration of DOC with dilution, accentuated by increased consumption of organic matter in these regions.

Recent studies have shown that apparently conservative behavior can be the result of the simultaneous existence of sources and sinks having similar magnitudes, resulting in very small changes in the overall DOC concentration. ${ }^{53}$

There was a good correlation between DOC and the intensities of fluorescence peaks II, III and IV, during both of the periods studied (Figures 6 and 7), with correlations being somewhat lower for the samples collected in October 2007. However, no correlation was observed between the DOC concentration and the intensity of peak I. Correlation is not always observed between fluorescent organic matter and DOC, since the fluorescent material represents only a fraction of total DOC. Another contributing factor is that the sources and sinks of fluorescent material are not necessarily the same as those of the total dissolved organic matter. ${ }^{32,54-55}$

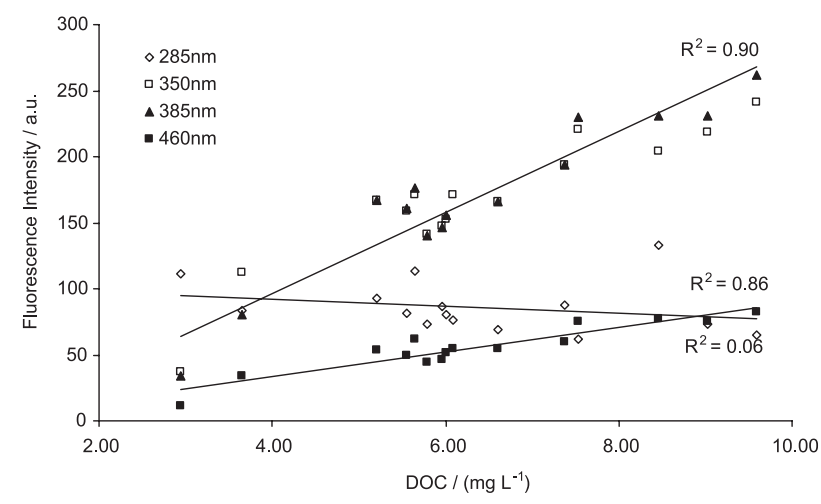

Figure 6. Variation of the fluorescence intensity of the different peaks according to the DOC concentration (July 2008).

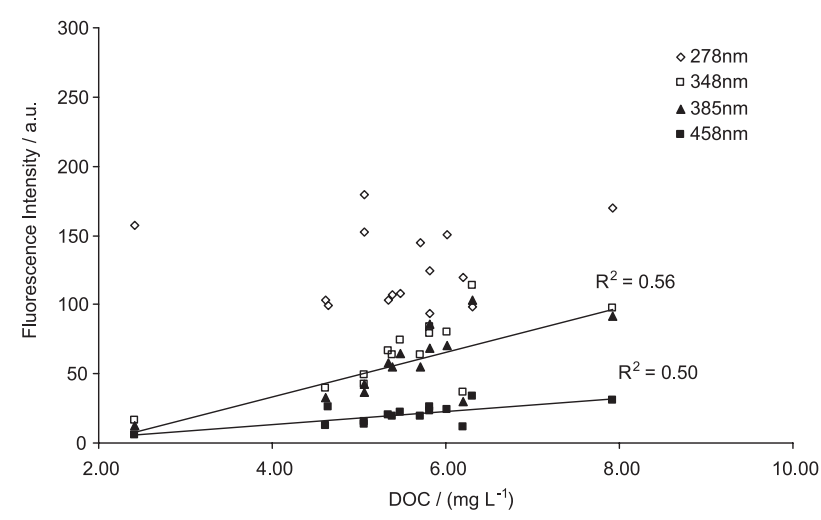

Figure 7. Variation of the fluorescence intensity of the different peaks according to the DOC concentration (October 2007).

Ratios between the intensities of the different peaks have been used to accompany changes in the relative amounts of different fluorophores. ${ }^{32}$ Peak I is representative of protein-like compounds, and therefore reflects aquatic biological activity. The relationship $\mathrm{I}_{\text {peak I }} / \mathrm{I}_{\text {peak IV }}$ (Figure 8) therefore enables monitoring of the autochtone production of the estuary.

Here, $I_{\text {peak I }} / I_{\text {peak IV }}$ remained fairly constant up to a salinity of 12 , and then increased with salinity, especially in the dry period when climatic conditions were favorable for phytoplankton activity. This change seems to indicate that primary production was very low in much of the estuary, and increased at salinities greater than 20. Substantial production of protein-like substances 


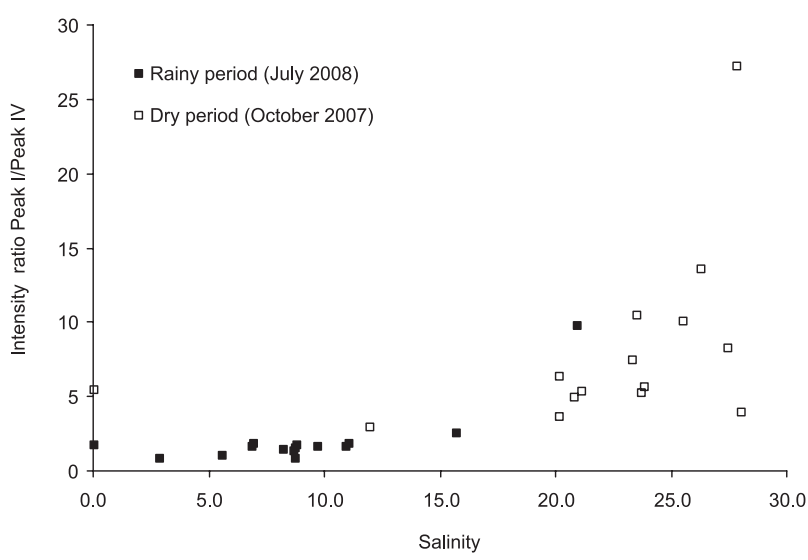

Figure 8. Variation with salinity of the Peak I / Peak IV fluorescence intensity ratio.

was restricted to the region of greatest marine influence (s > 20), and showed no obvious direct relationship with DOC, which explains the lack of correlation between DOC and the intensity of peak I.

In view of the short sampling periods, the observations presented here should be considered as preliminary information concerning seasonal variability.

\section{Complexation of DOM with $\mathrm{Cu}(\mathrm{II})$}

The loadings of anthropogenic metal pollutants in coastal environments have increased substantially in recent years. Dissolved organic matter is an effective complexation agent for trace metals, and can therefore make a large contribution to their lifecycles in aquatic environments. ${ }^{56}$ In estuarine regions, the highly variable environmental conditions influence the speciation of contaminants as well as the nature and complexation properties of the DOM. Studies of the complexation properties of estuarine DOM are therefore vital in order to better understand the impact and transport of metallic pollutants at the interface between fluvial waters and the marine environment.

The technique of fluorescence suppression, based on the modified Stern-Volmer model, ${ }^{37}$ was employed for a preliminary assessment of the complexation potentials of fluorescent sites of DOM in the Piauí River estuary. The modified Stern-Volmer equation has the form:

$\mathrm{I}_{\mathrm{o}} /\left(\mathrm{I}_{\mathrm{o}}-\mathrm{I}\right)=1 /(\mathrm{fK}[\mathrm{Cu}])+1 / \mathrm{f}$

Where, $I$ and $I_{o}$ are the fluorescence intensities of the DOM in the sample, with and without addition of $\mathrm{Cu}(\mathrm{II})$, respectively. $\mathrm{K}$ is the conditional complexation constant, and $\mathrm{f}$ is the fraction of the DOM that participates in the complexation. The values of $\mathrm{K}$ and $\mathrm{f}$ can be estimated from the plot of $\mathrm{I}_{\mathrm{o}} /\left(\mathrm{I}_{\mathrm{o}}-\mathrm{I}\right)$ against $1 /[\mathrm{Cu}]$.
This procedure only considers the behavior of the fluorescent sites that participate in the complexation, and does not enable evaluation of non-fluorescent complexation sites. Despite this drawback, the method has been used previously in many studies. ${ }^{57-60}$ The model also considers that the suppression (quenching) is static, leading to formation of a stable and non-fluorescent metal-fluorophore complex. Copper is a metal that has been widely used in this type of experiment, since it is both an effective suppressor of the fluorescence of humic substances and shows a strong association with colloidal molecules.

The fluorescent organic matter undergoes major changes and varies in nature during estuarine transport. This preliminary study considered the complexation properties of the material, using a sample that enabled assessment of the complexation features of the three fluorophores. Sample P5, collected in the middle of the estuary, was used for this purpose since the three fluorophores were present at concentrations that allowed the monitoring of the decrease in fluorescence intensities during successive additions of copper.

The decreases in the intensities of the different fluorescence peaks, as a function of increased $\mathrm{Cu}$ (II) concentration, are shown in Figure 9. All three principal fluorescence peaks showed reduced intensities as the $\mathrm{Cu}$ (II) concentration increased, although the relative intensity reductions were not identical, reflecting the different behaviors of the fluorophores with respect to complexation. The maximum fluorescence intensities of each peak relative to the concentration of $\mathrm{Cu}$ (II) were used to determine the parameters of complexation. The plot of $I_{o} /\left(I_{o}-I\right)$ against $1 /[\mathrm{Cu}]$ was highly linear for the three types of fluorophore (Figure 10). The complexation parameters calculated for the different peaks are presented in Table 2, and were different depending on the fluorophore. Values of $\log \mathrm{K}$ in the range 4.6 to 5.6 have been reported in the literature for natural estuarine waters, ${ }^{61,62}$ in good agreement with the values obtained here. The values of $\mathrm{f}$ confirm the complexation potentials of the tryptophan and humic type fluorophores, and indicate the capacity for complexation of the proteinlike compounds (peak I). The production of protein-like material therefore ensures that complexation can occur in the region of higher salinity, where the fluorescence intensities of peaks II and III were greatly diminished due to dilution. This result is in agreement with the recent study of Vacher ${ }^{62}$ that showed a strong participation of protein-like fluorophores in the complexation of copper in estuarine regions, where there is a high production of these materials as a result of autotrophic and heterotrophic activity. 


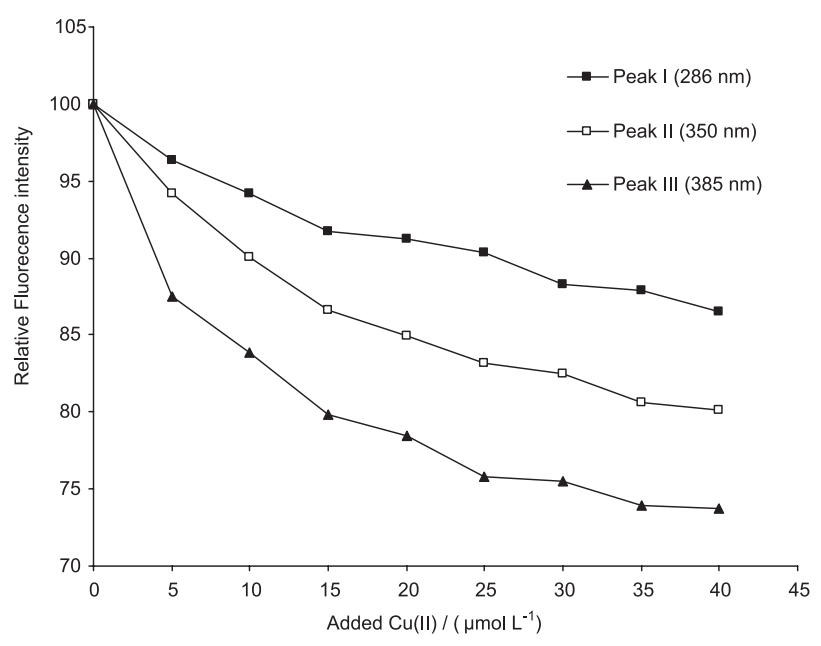

Figure 9. Decrease (fluorescence quenching) of the intensities of peaks I, II and III, following addition of $0.01 \mathrm{~mol} \mathrm{~L}^{-1} \mathrm{Cu}$ (II) solution.

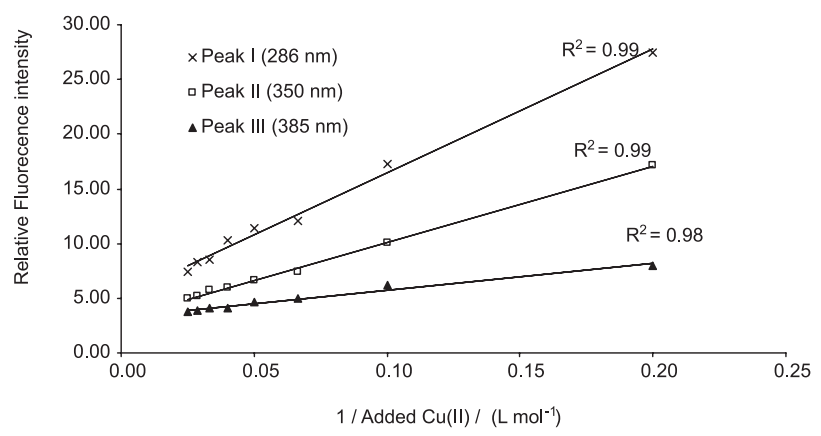

Figure 10. Stern-Volmer model plot for dissolved organic matter in water from the Piauí River ( salinity $=13.4 ; \mathrm{pH}=7.4$ ).

Table 2. Complexation parameters calculated using the modified SternVolmer model for the different DOM fluorescence peaks (means \pm standard deviations) of the samples collected during July 2008 at site 5 in the Piauí River estuary

\begin{tabular}{lcccc}
\hline Peak & Em / nm & $\log \mathrm{K}$ & $\mathrm{f} /(\%)$ & $\mathrm{R}^{2}$ \\
\hline I & 286 & $4.60 \pm 0.06$ & $21.0 \pm 0.2$ & 0.99 \\
II & 350 & $4.78 \pm 0.12$ & $30.8 \pm 0.5$ & 0.99 \\
III & 385 & $5.23 \pm 0.13$ & $36.8 \pm 0.8$ & 0.98 \\
\hline
\end{tabular}

\section{Conclusions}

This work provides the first information concerning the properties of the dissolved organic matter in the estuary of the Piauí River of Northeast Brazil. Analysis of synchronized fluorescence spectra showed that the DOM was mainly composed of humic substances and organics associated with urban and industrial wastes discharged into the Piauí River and transported downstream to the estuarine region. During the dry period, there was a predominance of organic matter derived from primary microbial production, associated with coastal biological activity. Fluorescence intensities were greater during the rainy period, providing evidence that the variation in fluorescence properties of the DOM was dictated mainly by the fluvial discharge rate and dilution of terrestrial DOM with coastal ocean water.

The fluorescent DOM showed behavior that was non-conservative, with production of fluorescent organic material in the region of low salinity and removal in the intermediate part of the estuary.

DOC showed behavior that was conservative during the dry period and non-conservative during the rainy period, with the addition of organic matter in the upper estuary. This shift was attributed to increased concentrations of DOC caused by desorption of organic compounds from particulate matter in the maximum turbidity zone or the resuspension of bottom sediment.

The technique of fluorescence suppression based on the simplified Stern-Volmer model was employed to evaluate the complexing of different fluorescent sites with $\mathrm{Cu}(\mathrm{II})$. The values of the conditional complexation constant $(\log \mathrm{K})$ varied from 4.60 to 5.23 , and were in agreement with values reported in the literature for natural estuarine waters. The fraction of the fluorophores that was available for complexation (f) varied between 21.0 and $36.8 \%$, confirming the complexation potentials of three types of fluorophore and providing evidence for the complexation capacity of protein-like compounds.

In view of the short sampling periods, the observations presented here should be considered as preliminary information concerning seasonal variability.

\section{Supplementary Information}

Supplementary data are available free of charge at http://jbcs.sbq.org.br as PDF file.

\section{Acknowledgments}

The authors are grateful to Conselho Nacional de Desenvolvimento Científico e Tecnológico (CNPq) for a studentship and for financial support.

\section{References}

1. Hedges, J. I.; Keil, R. G.; Mar. Chem. 1997, 49, 81.

2. Spencer, R. G. M.; Bolton, L.; Baker, A.; Water Res. 2007, 41, 2041.

3. Lonborg, C.; Sondergaard, M.; Estuar. Coast. Shelf Sci. 2009 , $81,513$.

4. Lara, R. J.; Thomas D. N.; Mar. Chem. 1995, 51, 193.

5. Opsahl, S.; Benner, R.; Nature 1997, 386, 480.

6. McCarthy, M. D.; Hedges, J. I.; Benner, R.; Chem. Geol. 1993, 107, 503. 
7. Patel-Serrentino, N.; Mounier, S.; Lucas, Y.; Benain, J. Y.; Sci. Tot. Environ. 2004, 321, 231.

8. Harvey, G. R.; Boran, D. A.; Chesal, L. A.; Tokar, J. M.; Mar. Chem. 1983, 12, 119.

9. Carder, K. I.; Steward, R. G.; Harvey, G. R.; Ortner, P. B.; Limnol. Oceanogr. 1989, 34, 68.

10. Kowalczuk, P.; Durako, M. J.; Young, H.; Kahn, A. E.; Cooper, W. J.; Gonsior, M.; Mar. Chem. 2009, 113, 182.

11. Vahatalo, A. V.; Zeep, R. G.; Environ. Sci. Technol. 2005, 39, 6985 .

12. Stedmon, C. A.; Markager, S.; Tranvik, L.; Kronberg, L.; Slatis, T.; Martinsen, W.; Mar. Chem. 2007, 104, 227.

13. Anderson, D. O.; Gjessing, E. T.; Water Res. 2000, 36, 2372.

14. Hautala, K.; Peuravuori, J.; Pihlaja, K.; Water Res. 2000, 34 , 246.

15. McKnight, D. M.; Boyle, E. W.; Westwehoff, P. K.; Doran, P. T.; Kulbe, T.; Anderson, D. T.; Limnol. Oceanogr. 2001, 46, 38.

16. Chen, J.; Gu, B. H.; Leboeuf, E. J.; Pan, H. J.; Dai, S.; Chemosphere 2002, 48, 59.

17. Stedmon, C.A.; Markager, S.; Bro, R.; Mar. Chem. 2003, 82, 239.

18. Hudson, N. J.; Baker, A.; Reynolds, D.; Rivers Res. Appl. 2007, 23,631 .

19. Hur, J.; Hwang, S.; Shin, J.; Water, Air, Soil Pollut. 2008, 191, 231.

20. Dalzell, B. J.; Minor, E. C.; Mopper, K. M.; Org. Geochem. 2009, 40, 243.

21. Rodrigues, A.; Britto, A.; Janknecht, P.; Proença, M. F.; Nogueira, R.; J. Environ. Monit. 2009, 11, 377.

22. Lakowicz, J. R.; Principles of Fluorescence Spectroscopy, $2^{\text {nd }}$ ed.; Kluwer Academic/Plenum Publishers: New York, 1999.

23. Wu, J.; Pons, M. N.; Potier, O.; Water Sci. Technol. 2006, 53, 449.

24. Lu, X. Q.; Jaffé, R.; Water Res. 2001, 35, 179.

25. Henderson, R. K.; Baker, A.; Murphy, K. R.; Hambly, A.; Stuetz, R. M.; Khan, S. J.; Water Res. 2009, 43, 863.

26. Jaffé, R.; Boyer, J. N.; Lu, X.; Maie, N.; Yang, C.; Scully, N. M.; Mock, S.; Mar. Chem. 2004, 84, 195.

27. Hedges, J. I.; Keil, R. G.; Benner, R.; Org. Geochem. 1997, 27 , 717.

28. Benner, R.; Opsahl, S.; Org. Geochem. 2001, 32, 597.

29. Loh, A. N.; Bauer, J. F.; Canuel, E. A.; Limnol. Oceanogr. 2006, 51,1421

30. De Souza Sierra, M. M.; Donard, O. F. X.; Lamotte, M.; Mar. Chem. 1997, 58, 51 .

31. Parlanti, E.; Wörz, K.; Geoffroy, L.; Lamotte, M.; Org. Geochem. 2000, 31, 1765.

32. Huguett, A.; Vacher, L.; Relexans, S.; Saubusse, S.; Froidefond, J. M.; Parlanti, E.; Org. Geochem. 2009, 30, 706.

33. Huguett, A.; Vacher, L.; Saubusse, S.; Etcheber, H.; Abril, G.; Relexans, S.; Ibalot, F.; Parlanti, E.; Org. Geochem. 2010, 41, 595.

34. Andrade, R. C. B.; Souza, M. F. L.; Couto, E. C. G.; Quim. Nova 1998, 21, 424.
35. Souza, M. F. L.; Couto, E. C. G.; Rev. Bras. Biol. 1999, 59 , 195.

36. Hudson, N. J.; PhD Thesis, University of Birmingham, UK, 2010. http://etheses.bhan.ac.uk/780/ accessed in April 2011.

37. Esteves da Silva, J. C. G.; Machado, A. A. C.; Oliveira, C. J. S.; Pinto, M. S. S. D. S.; Talanta 1998, 45, 1155.

38. Vo-Dihn, T.; Anal. Chem. 1978, 50, 396.

39. Coble, P. G.; Green, S. A.; Blough, N. V.; Gagosian, R. B.; Nature 1990, 348, 432.

40. De Souza Sierra, M. M.; Donard, O. F. X.; Lamotte, M.; Belin, C.; Ewald, M.; Mar. Chem. 1994, 47, 12.

41. Determann, S.; Reuter, R.; Wagner, P.; Willkomm, R.; Deep-Sea Res. 1994, 41, 659.

42. Lu, X. Q.; Childers, D. I.; Hanna, J. V.; Maie, N.; Jaffé, R.; Water Res. 2003, 37, 2599.

43. Miano, T. M.; Senesi, N.; Sci. Tot. Environ. 1992, 117-118, 41.

44. Chen, W.; Westerhoff, P.; Leenheer, J. A.; Booksh, K.; Environ. Sci. Technol. 2003, 37, 5701.

45. Baker, A.; Curry, M.; Water Res. 2004, 38, 2605.

46. Baker, A.; Ward, D.; Lieten, S. H.; Periera, R.; Simpson, E. C.; Slater, M.; Water Res. 2004, 38, 2934.

47. Kubista, M.; Sjobck, R.; Eriksson, S.; Albinsson, B.; Analyst 1994, 119, 417.

48. Maie, N.; Boyer, J. N.; Yang, C.; Jaffé, R.; Hydrobiologia 2006, $569,135$.

49. Rochelle-Newall, E. J.; Fisher, T. R.; Mar. Chem. 2002, 77, 7.

50. Abril G.; Nogueira M.; Etcheber H.; Cabeçadas G.; Lemaire E.; Brogueira M. J.; Estuar. Coast. Shelf Sci. 2002, 54, 241.

51. Callahan, J.; Dai, M.; Chen, R. F.; Li, X.; Lu, Z.; Huang, W.; Mar. Chem. 2004, 89, 211.

52. Miller, A. E. J.; Estuar. Coast. Shelf Sci. 1999, 27, 595.

53. Raymond, P. A.; Bauer J. E.; Aquatic Microb. Ecol. 2000, $22,1$.

54. Klinkhammer, G. P.; Manus, J. M.; Colbert, D.; Rudnicki, M. D.; Geochim. Cosmochim. Acta 2000, 64, 2765.

55. Ferrari, C. M.; Mar. Chem. 2009, 70, 339.

56. Christensen, J. B.; Jensen, D. L.; Christensen, T. H.; Water Res. 1996, 30, 3037.

57. Lee, D. Y.; Lin, C. F.; Huong, L. M.; Lo, K. S.; Chinese Inst. Environ. Engr. 1992, 2, 51.

58. Fang Lin, C.; Yuan Lee, D.; Tsai Chen, W.; Lo, K. S.; Environ. Pollut. 1995, 87, 181.

59. Lombardi, A. T.; Jardim, W. F.; J. Braz. Chem. Soc. 1997, 8 , 339.

60. Sodré, F. F.; Grassi, M. T.; J. Braz. Chem. Soc. 2007, 18, 1136.

61. Berger, P.; Ewald, M.; Liu, D.; Weber, J. H.; Mar. Chem. 1984, $14,289$.

62. Vacher, L.; PhD Thesis, Université Bordeaux 1, France, 2004. http://grenet.drimm.u-bordeaux 1.fr/pdf/2004/VACHER_ LILIAN_2004.pdf accessed in February 2011.

Submitted: March 1, 2011 Published online: September 20, 2011 


\title{
Characterization of Dissolved Organic Matter in the Piauí River Estuary, Northeast Brazil
}

\author{
Adnivia Santos Costa, Elisangela de Andrade Passos, * Carlos A. B. Garcia and \\ José do Patrocinio H. Alves
}

Departamento de Química, Universidade Federal de Sergipe, 49100-000 São Cristóvão-SE, Brazil

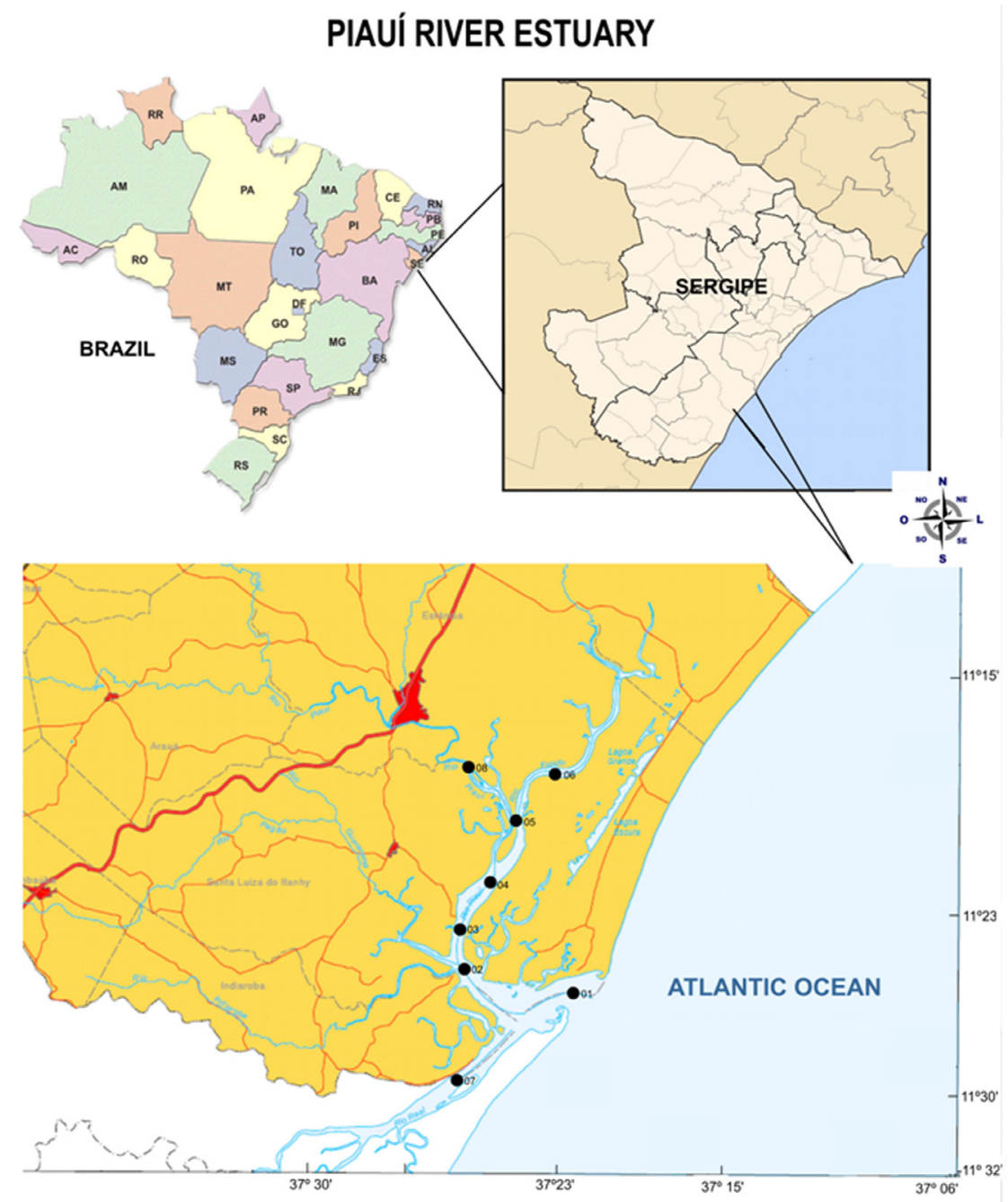

Figure S1. Locations of the sampling sites in the estuary of the Piauí River, Sergipe State, Brazil. 